\title{
Tubular metaplasia in Bowman's capsule
}

\author{
A. MILFORD WARD \\ From the Department of Pathology, University of Sheffield
}

SYNOPSIS Proximal tubular type metaplasia of the epithelium of Bowman's capsule $\overrightarrow{\overrightarrow{k S}}$ described in a fit young adult male. This form of metaplasia is unlike those previously described and could cause initial confusion if encountered in a percutaneous renal biopsy.

The upper part of the nephron can be divided into the renal corpuscle, or Bowman's capsule, the neck portion, and the proximal tubule (Rouiller, 1969). In man Bowman's capsule is lined by an inconspicuous layer of flattened squamous cells (Allen, 1962; Brewer, 1964; Heptinstall, 1967); in the mink and mouse the parietal capsular epithelium is cuboidal (Crabtree, 1940; Rouiller, 1969). The neck portion, seen in lower animals but not in man, is lined by an epithelium which has the cytological characteristics of the proximal tubule (DuBois, 1969). Two types of metaplasia of the capsular epithelium have been described, an adenomatoid type (Eisen, 1946; Chappell and Phillips, 1950; Nachman, 1962; Macpherson, 1963) and a columnar type (Lloyd Thomas, 1953; Finckh and Joske, 1954). A third variety is now described.

\section{Case Report}

A fit young adult male (aged 19) died from multiple injuries sustained in a road traffic accident. Necropsy revealed no evidence of preexisting disease. The kidneys were of normal size, weight, and texture.

\section{HISTOPATHOLOGY}

Twenty-five per cent of the glomeruli show a high cuboidal epithelium replacing the normal flattened epithelium of Bowman's capsule. The cuboidal Recieived for publication 19 January 1970. epithelium is usually situated opposite to the vascular pole of the glomerular tuft, but may extend around much of the capsule (Figs. 1 and 22 The cells have regular nuclei situated towards the basal pole of the cell, and an eosinophilic cytor plasm. Some cells show some basal striatio whilst all show a prominent brush border which stains intensely with the periodic-acid-Schif (PAS) method. The cytological characteristics are identical to those of the neighbouring proxim tubular epithelial cells. In some glomeruli direct continuity can be demonstrated between the proximal tubular epithelium and the metaplast epithelium of Bowman's capsule (Figs. 3 and 4. No other abnormalities were detected in the kidney.

\section{Discussion}

Instances of metaplasia of the capsular epitheliun are reported rarely in the literature, and one must assume that this is an uncommon finding. The two types so far described differ on cytological and clinical grounds (Table).

The adenomatoid type (Eisen, 1946) occurs both sexes and at varying ages. All patients have advanced, disseminated malignancy, usually i volving the liver. The columnar type (Lloy Thomas, 1953) occurs in both sexes but all patien $\mathbb{8}$ are under 25 years. No patient in this group had any evidence of malignant disease, although four had diabetes (Finckh and Joske, 1954).

The present case, representing a third variety 


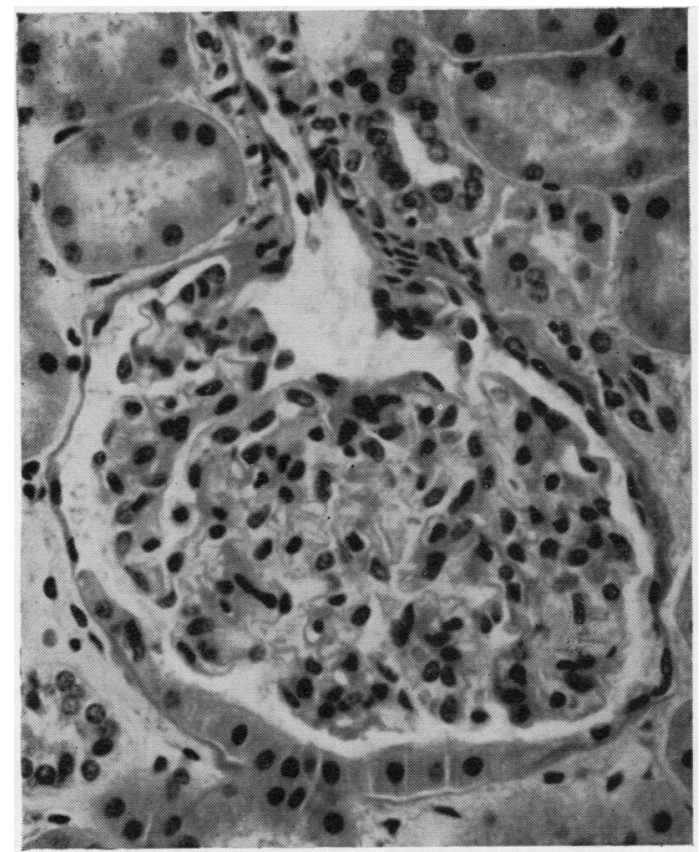

Fig. 1 Glomerulus showing prominent tubular metaplasia of the capsular epithelium opposite the vascular pole of the glomerulus. Haematoxylin and eosin $\times 125$.

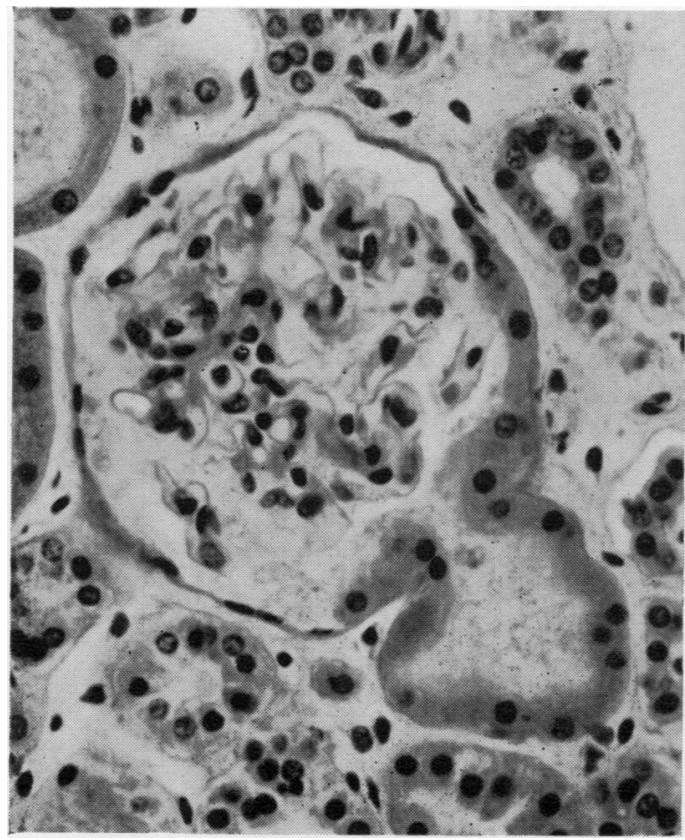

Fig. 3 Glomerulus showing continuity between metaplastic capsular epithelium and tubular epithelium. Haematoxylin and eosin $\times 125$.

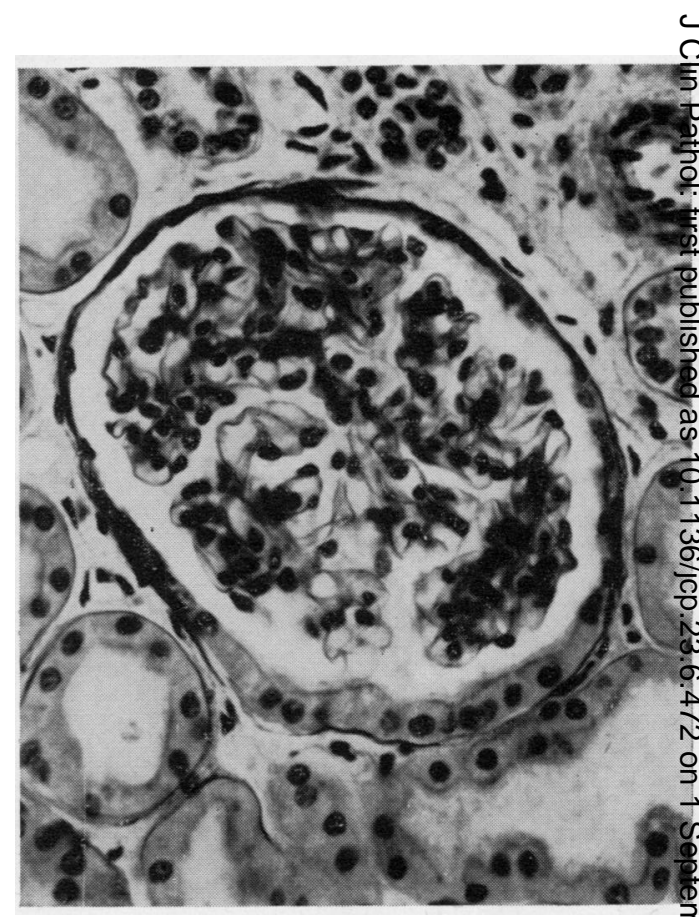

Fig. 2 Tubular metaplasia with prominent brush border. Periodic acid Schiff $\times 125$.

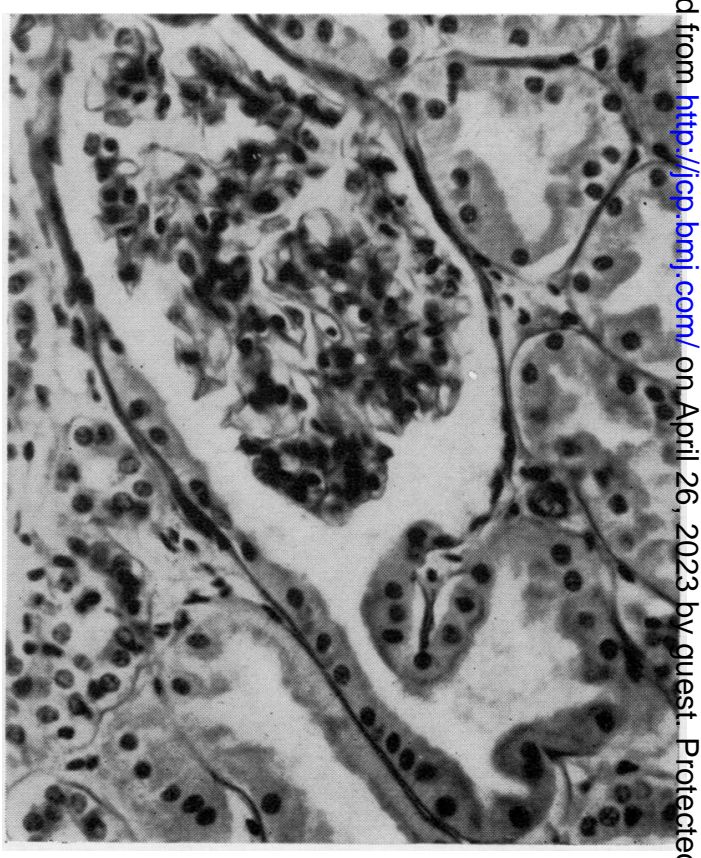

Fig. 4 Glomerulus showing continuity between 


\begin{tabular}{|c|c|c|c|c|}
\hline \multicolumn{2}{|c|}{ Case Author } & \multicolumn{2}{|c|}{ Sex Age } & \multirow{2}{*}{$\begin{array}{l}\text { Comment } \\
\begin{array}{l}\text { Metastatic carcinoma } \\
\text { gallbladder }\end{array}\end{array}$} \\
\hline 1 & $\begin{array}{l}\text { Adenomatoid type } \\
\text { Eisen (1946) }\end{array}$ & $\mathbf{F}$ & 54 & \\
\hline 2 & Chappell \& Phillips (1950) & $\mathbf{M}$ & 16 & $\begin{array}{l}\text { Metastatic carcinoma } \\
\text { adrenal }\end{array}$ \\
\hline 3 & Nachman (1962) & $\mathbf{F}$ & $6 / 12$ & $\begin{array}{l}\text { Metastatic carcinoma } \\
\text { liver }\end{array}$ \\
\hline 4 & Macpherson (1963) & $\mathbf{F}$ & 74 & $\begin{array}{l}\text { Metastatic carcinoma } \\
\text { (?) breast }\end{array}$ \\
\hline & Columnar & & & \\
\hline $\begin{array}{l}5 \\
6\end{array}$ & $\begin{array}{l}\text { Lloyd-Thomas (1953) } \\
\text { Finckh \& Joske (1954) }\end{array}$ & $\begin{array}{l}\mathbf{F} \\
\mathbf{M}\end{array}$ & $\begin{array}{l}14 \\
14\end{array}$ & $\begin{array}{l}\text { Type II nephritis } \\
\text { Diabetes: no evidence } \\
\text { of renal disease }\end{array}$ \\
\hline 7 & Finckh \& Joske (1954) & $\mathbf{M}$ & 15 & $\begin{array}{l}\text { Diabetes: no evidence } \\
\text { of renal disease }\end{array}$ \\
\hline 8 & Finckh \& Joske (1954) & $\mathbf{M}$ & 16 & $\begin{array}{l}\text { Diabetes: no evidence } \\
\text { of renal disease }\end{array}$ \\
\hline 9 & Finckh \& Joske (1954) & $\mathbf{F}$ & 16 & $\begin{array}{l}\text { Diabetes: no evidence } \\
\text { of renal disease }\end{array}$ \\
\hline 10 & Finckh \& Joske (1954) & $\mathbf{F}$ & 25 & $\begin{array}{l}\text { ?Systematic lupus: no } \\
\text { evidence of renal } \\
\text { disease }\end{array}$ \\
\hline 11 & $\begin{array}{l}\text { Tubular type } \\
\text { Present case }\end{array}$ & $\mathbf{M}$ & 19 & $\begin{array}{l}\text { No evidence of renal } \\
\text { disease }\end{array}$ \\
\hline
\end{tabular}

Table Two types of metaplasia of the capsular epithelium

metaplasia of the capsular epithelium, has features in common with the columnar type, with the exception of the prominence of the cytological features of proximal tubular epithelium. It seems unlikely that this feature would have been overlooked in the case described by Lloyd-Thomas (1953) as the PAS method was used to demonstrate the basement membrane thickening of type II nephritis.

The aetiology of this lesion is obscure. Finckh and Joske (1954) suggested persistence of some foetal structure or potentiality, but neither columnar nor tubular change is seen in foetal or neonatal material. It is possible that it represents a maldevelopment of the renal corpuscle and that the upper part of the proximal tubules has had to dilate to accommodate the glomerular tuft. If thiss were the case, one would expect some evidence of incompetence of the capsulo-tubular junction wi prolapse of the glomerular tuft. This is not see? although Finckh and Joske (1954) did note this feature once in one patient. Figures 3 and $y_{4}$ emphasize the competence of the capsulo-tuburar junction in this patient.

The adenomatoid metaplasia described Eisen (1946) may well have a different aetiologyळ

The lesion appears to have no pathologicol significance.

I wish to thank Dr H. H. Pilling, H.M. Coron for the City of Sheffield and the West Riding of Yorkshire, Rotherham Division, for permission to publish details of this case.

\section{References}

Allen, A. C. (1962). The Kidney, 2nd ed., p. 34. Churchef, London.

Brewer, D. B. (1964). Renal Biopsy, p. 10. Arnold, Londa.

Chappell, R. H., and Phillips, J. R. (1950). Adenomatoid changos of renal glomerular capsular epithelium associated w adrenal tumor. Arch. Path., 49, 70-72.

Crabtree, C. (1940). Sex differences in the structure of Bowman's capsule in the mouse. Science, 91, 299.

DuBois, A. M. (1969). In The Kidney, edited by C. Rouiller ad A. F. Muller, vol. I, p. 29. Academic Press, New York \& London.

Eisen, H. N. (1946). Adenomatoid transformation of the glome lar capsular epithelium. Amer. J. Path., 22, 597-601.

Finckh, E. S., and Joske, R. A. (1954). The occurrence of columngr epithelium in Bowman's capsule. J. Path. Bact., 68, 646-648.

Heptinstall, R. H. (1967). Pathology of the Kidney, p. Churchill, London.

Lloyd-Thomas, H. G. L. (1953). Type 2 nephritis relapsing years after onset, with 2 full-term pregnancies occurriag during the course of the disease. Proc. roy. Soc. Med., 715-716.

Macpherson, D. J. (1963). Metaplasia of renal glomerula rcapsu偻 epithelium. J. clin. Path., 16, 220-222.

Nachman, R. L. (1962) Metaplasia of parietal capsular epithelium of renal glomerulus. Arch. Path., 73, 48-52.

Rouiller, C. (1969). In The Kidney edited by C. Rouilfer and A. F. Muller, vol. I, p. 74. Academic Press, NEु York \& London. 